\title{
Updates on the Disinfection and Infection Control Process of the Accredited Endoscopy Unit
}

\author{
Jeong Eun Shin ${ }^{1}$, Yunho Jung ${ }^{2}$, Jeong Hoon Lee ${ }^{3}$, Byoung Kwan Son ${ }^{4}$, Jae-Young Jang ${ }^{5}$, Hyung-Keun Kim ${ }^{6}$, Byung Ik Jang ${ }^{7}$ \\ and The Quality Management Committee and the Disinfection Management Committee of Korean Society of Gastrointestinal \\ Endoscopy \\ ${ }^{1}$ Department of Internal Medicine, Dankook University College of Medicine, Cheonan, ${ }^{2}$ Department of Internal Medicine, Soonchunhyang \\ University College of Medicine, Cheonan, ${ }^{3}$ Department of Internal Medicine, University of Ulsan College of Medicine, Seoul, ${ }^{4}$ Department of \\ Internal Medicine, Eulji University College of Medicine, Seoul, ${ }^{5}$ Department of Internal Medicine, Kyung Hee University College of Medicine, \\ Seoul, ${ }^{6}$ Division of Gastroenterology, Department of Internal Medicine, Uijeongbu St. Mary's Hospital, College of Medicine, The Catholic \\ University of Korea, Uijeongbu, ${ }^{7}$ Department of Internal Medicine, Yeungnam University College of Medicine, Daegu, Korea
}

A thorough disinfection and infection control process associated with gastrointestinal endoscopy is highly important for the health and safety of the examinee and the medical staff involved in the procedure. Endoscopic reprocessing and disinfection are two of the most important steps in quality control of endoscopy. In 2019, the Korean Society of Gastrointestinal Endoscopy updated the Accreditation of Qualified Endoscopy Unit assessment items for these quality indicators. Assessment of disinfection and infection control comprises 28 mandatory items in the categories of disinfection education, pre-cleaning, cleaning, disinfection, rinsing, drying, reprocessing, storage, endoscopic accessories, water bottle and connectors, space/facilities, personal protective equipment, disinfection ledger, and regulations regarding infection control and disinfection.

The updated Accreditation of Qualified Endoscopy Unit assessment items are useful for improving the quality of endoscopy by ensuring thorough inspection of endoscopic disinfection and infection control. Clin Endosc 2019;52:443-450

Key Words: Disinfection; Education; Endoscopy; Infection control; Quality control

\section{INTRODUCTION}

Disinfection and infection control associated with gastrointestinal endoscopy is aimed at preventing the development of infectious diseases by managing disease-causing microorganisms that can spread after endoscopy. Endoscopic reprocessing and disinfection are two of the most important steps in quality control of endoscopy. In 2019, the Korean Society of Gastrointestinal Endoscopy (KSGE) updated the Accredi-

Received: September 2, 2019 Revised: September 22, 2019

Accepted: September 23, 2019

Correspondence: Jeong Eun Shin

Department of Internal Medicine, Dankook University College of Medicine, 201 Manghyang-ro, Dongnam-gu, Cheonan 31116, Korea

Tel: +82-41-556-3052, Fax: +82-41-556-3256, E-mail: dreun@dankook.ac.kr ORCID: https://orcid.org/0000-0001-5706-3967

(cc) This is an Open Access article distributed under the terms of the Creative Commons Attribution Non-Commercial License (http://creativecommons.org/ licenses/by-nc/3.0) which permits unrestricted non-commercial use, distribution, and reproduction in any medium, provided the original work is properly cited. tation of Qualified Endoscopy Unit (AQEU) assessment items for disinfection and infection control. The AQEU assessment of disinfection and infection control comprises 28 mandatory items in the following categories (Table 1): 2, disinfection education; 2, pre-cleaning; 2, cleaning; 4, disinfection; 1, rinsing; 2, drying; 1, reprocessing; 2, storage; 1 , endoscopic accessories; 1 , water bottle and connectors; 4 , space/facilities; 2 , personal protective equipment (PPE); 1, disinfection ledger; and 3, regulations regarding infection control and disinfection. This document introduces the updated AQEU assessment items for disinfection and infection control. 
Table 1. The Accreditation of Qualified Endoscopy Unit Assessment Items for Disinfection and Infection Control Process

\begin{tabular}{|c|c|c|}
\hline Category & AQEU assessment items & Grade \\
\hline $\begin{array}{l}\text { Disinfection education } \\
\text { ( } 2 \text { items) }\end{array}$ & $\begin{array}{l}\text { 1. All endoscopists must have acquired at least } 6 \text { credits of disinfection education within } 3 \text { years. } \\
\text { 2. Workers who clean and disinfect endoscopes must have acquired at least } 3 \text { credits of disinfec- } \\
\text { tion education within } 3 \text { years. }\end{array}$ & Mandatory \\
\hline $\begin{array}{l}\text { Pre-cleaning } \\
\quad(2 \text { items })\end{array}$ & $\begin{array}{l}\text { 1. Upon completion of an endoscopic examination, foreign objects on the surface of the endo- } \\
\text { scope must be removed immediately and aspirated with detergent solution. } \\
\text { 2. The endoscope must be placed in a designated container or basket and transferred to the clean- } \\
\text { ing and disinfection room, which is separate from the examination room. }\end{array}$ & Mandatory \\
\hline $\begin{array}{l}\text { Cleaning } \\
\text { (2 items) }\end{array}$ & $\begin{array}{l}\text { 1. The biopsy channel, all valves, and the suction channel must be scrubbed with a brush. } \\
\text { 2. Valves and rubber stoppers must be replaced after each use. }\end{array}$ & Mandatory \\
\hline $\begin{array}{l}\text { Disinfection } \\
\text { (4 items) }\end{array}$ & $\begin{array}{l}\text { 1. High-level disinfectant must be used. } \\
\text { 2. When immersing parts in disinfectant, the biopsy and suction channels must be completely } \\
\text { filled with disinfectant solution. } \\
\text { 3. Minimal effective concentrations of high-level disinfectant must be checked and replaced ap- } \\
\text { propriately. } \\
\text { 4. Disinfectant immersion time should follow the time recommended by the disinfectant manu- } \\
\text { facturer. }\end{array}$ & Mandatory \\
\hline Rinsing (1 item) & 1. Proper rinsing is required after disinfection. & Mandatory \\
\hline $\begin{array}{l}\text { Drying } \\
\text { (2 items) }\end{array}$ & $\begin{array}{l}\text { 1. After rinsing, examinations must be performed after the endoscopy equipment has completely } \\
\text { dried. } \\
\text { 2. Moisture from the exterior of the endoscope and water remaining in the suction channel must } \\
\text { be eliminated and then dried by hanging vertically. }\end{array}$ & Mandatory \\
\hline $\begin{array}{l}\text { Reprocessing } \\
\text { (1 item) }\end{array}$ & 1. After each examination, one-on-one cleaning, disinfection, and rinsing must be performed. & Mandatory \\
\hline \multirow[t]{2}{*}{$\begin{array}{l}\text { Storage } \\
\text { (2 items) }\end{array}$} & $\begin{array}{l}\text { 1. Disinfected endoscopes must be stored in a dedicated cabinet by hanging vertically, ensuring } \\
\text { that the distal end of the endoscope does not touch the floor of the cabinet. }\end{array}$ & Mandatory \\
\hline & $\begin{array}{l}\text { 2. The cabinet for storing the disinfected endoscope must be located away from the contaminated } \\
\text { area. }\end{array}$ & Mandatory ${ }^{\text {a) }}$ \\
\hline $\begin{array}{l}\text { Endoscopic accessories } \\
(1 \text { item })\end{array}$ & $\begin{array}{l}\text { 1. Endoscopic accessories must be disposable products or reusable products that have been steril- } \\
\text { ized. }\end{array}$ & Mandatory \\
\hline $\begin{array}{l}\text { Water bottle and con- } \\
\text { nectors } \\
(1 \text { item })\end{array}$ & 1. Water bottle and connectors must be disinfected regularly and sterilized water must be used. & Mandatory \\
\hline \multirow[t]{2}{*}{$\begin{array}{l}\text { Space/facility } \\
\text { (4 items) }\end{array}$} & $\begin{array}{l}\text { 1. The endoscope cleansing and disinfection room must be located in an area separate from the } \\
\text { endoscopic examination room, and the room must be kept clean. } \\
\text { 2. The endoscope cleaning and disinfection room must be equipped with adequate ventilation } \\
\text { system. }\end{array}$ & Mandatory \\
\hline & $\begin{array}{l}\text { 3. The endoscope cleaning and disinfection area must be divided into contaminated and clean } \\
\text { zones. } \\
\text { 4. Reprocessed endoscopes must be transferred to the endoscopic examination room through a } \\
\text { path separate from that of the contaminated endoscopes. }\end{array}$ & Mandatory ${ }^{\text {a) }}$ \\
\hline $\begin{array}{l}\text { Personal protective } \\
\text { equipment ( } 2 \text { items })\end{array}$ & $\begin{array}{l}\text { 1. All persons performing endoscopic procedures must wear PPE. } \\
\text { 2. All workers cleansing and disinfecting endoscopes must wear PPE. }\end{array}$ & Mandatory \\
\hline $\begin{array}{l}\text { Disinfection ledger } \\
(1 \text { item })\end{array}$ & $\begin{array}{l}\text { 1. In relation to the reprocessing process, data must be managed to be able to differentiate pa- } \\
\text { tients, procedure name, the used endoscope and AER, and so on. }\end{array}$ & Mandatory \\
\hline $\begin{array}{l}\text { Regulations regarding } \\
\text { infection control and } \\
\text { disinfection } \\
\text { (3 items) }\end{array}$ & $\begin{array}{l}\text { 1. Guidelines stipulating infection control and endoscope cleaning and disinfection management } \\
\text { must be available. } \\
\text { 2. In-house disinfection education must be conducted for quality control of endoscope disinfection. } \\
\text { 3. Bacterial culture tests must be performed at least twice a year for quality control of endoscope } \\
\text { disinfection. }\end{array}$ & Mandatory \\
\hline
\end{tabular}

AER, automated endoscope reprocessor; AQEU, accreditation of qualified endoscopy unit; PPE, personal protective equipment.

a) Although this is a mandatory item, full compliance may be difficult with short-term preparation. Accordingly, if there are specific plans for future changes, the assessment may be deferred by 3 years until the next accreditation assessment. 


\section{RATIONALE BEHIND AQEU ASSESSMENT ITEMS FOR DISINFECTION AND INFECTION CONTROL}

\author{
Mandatory items 28 items
}

\section{Disinfection education: 2 items}

\section{All endoscopists must have acquired at least 6 credits of disinfection education within 3 years.}

Rationale: To prevent the spread of endoscopy-related infection, all endoscopists with the responsibility of supervising infection control in endoscopy must complete disinfection education and also take part in maintenance/continuing education on disinfection. Only experienced endoscopists may be involved in the reprocessing process and all new workers must learn the processes and theories related to endoscope disinfection. Accredited institutions or organizations should be in charge of education related to disinfection. Education on theory and practice can reduce the incidence of accidental infections and endoscopists' risk of and exposure to infection. Updated knowledge and techniques related to endoscope disinfection must be acquired continuously to prevent the spread of endoscopy-related infection and to guarantee quality of disinfection in endoscopic examinations, which must be maintained above an adequate level. Disinfection guidelines from other countries, including the United States, emphasize the need for endoscopists, who have the responsibility of supervising infection control in endoscopy, to participate in continuous training, education, and surveillance of workers who clean and disinfect endoscopes. ${ }^{1,2}$

\section{Workers who clean and disinfect endoscopes} must have acquired at least 3 credits of disinfection education within 3 years.

Rationale: Current knowledge and techniques related to endoscope disinfection must be acquired continuously to prevent the spread of endoscopy-related infection and to guarantee the quality of disinfection in endoscopic examinations, which must be maintained above an adequate level. Maintenance/continuing education on disinfection must be conducted for person(s) directly responsible for disinfection procedures, as well as all endoscopists with the responsibility of supervising infection control in endoscopy. The emphasis on continuous training, education, and surveillance of endoscope cleaning and disinfection workers is growing worldwide. ${ }^{1,2}$

\section{Pre-cleaning: 2 items}

1. Upon completion of an endoscopic examination, foreign objects on the surface of the endoscope must be removed immediately and aspirated with detergent solution.

Rationale: This is the first step in manual cleaning, which represents the most important process during which most bacteria could be removed prior to disinfection. Immediately upon the completion of an endoscopic procedure, foreign objects on the surface of the endoscope beside the bed must be removed with either a disposable cloth or gauze soaked in enzymatic detergent or sterilized water as quickly as possible. ${ }^{3}$ The endoscope is placed in detergent solution and aspirated to remove any residual contaminants remaining inside the biopsy channel. Subsequently, the process of running water through and blowing air through the biopsy channel must be repeated. Repeating this process of blowing air several times can help remove greater amounts of contaminants. If this step is not performed immediately after the procedure, bodily fluids and blood may coagulate and become difficult to remove during the subsequent disinfection step. Enzymatic detergents may have different constituents depending on the manufacturer, but they are all capable of effectively degrading contaminants that occur inside the body, such as blood, polysaccharides, lipids, and biofilm. Finally, after the air is suctioned, the endoscope is disconnected from the power source.

\section{The endoscope must be placed in a designated container or basket and transferred to the clean- ing and disinfection room, which is separate from the examination room. \\ Rationale: Immediately after pre-cleaning, the used en-} doscope is transferred to the endoscope reprocessing area before the residual contaminants have completely dried. To prevent potential infection from the contaminated endoscope being exposed to medical staff, patients, and/or the environment during transfer, the contaminated endoscope must be placed in a designated container or basket and transferred to the cleaning and disinfection room, which is separate from the examination room. ${ }^{1}$ The container used to transport the endoscope must be sufficiently large to avoid damage to the endoscope and to avoid allowing the tip of the endoscope to become twisted or tangled. If the distance to the cleaning area is far, the container must be covered during transfer. When transferring endoscopes, contaminated and disinfected endoscopes must be clearly labeled for visual identification. 


\section{Cleaning: 2 items}

\section{The biopsy channel, all valves, and the suction channel must be scrubbed with a brush.}

Rationale: The suction valve, air/water valve, and biopsy channel rubber stopper attached to the endoscope must be detached for cleansing and disinfection. After performing leakage testing to detect any damage to the endoscope, the endoscope is immersed in detergent solution, and the exterior of the endoscope is cleaned with gauze. For hard-to-reach areas inside the channels that are difficult to clean, properly sized brushes must be used to completely remove all contaminants from inside the channels. Rubber stoppers and valves detached from the endoscope must be cleaned with a brush. Proper manual cleaning can reduce pathogens present on the endoscope by $99.9 \%-99.999 \%$, but if manual cleaning is not performed properly, disinfection may be insufficient even after using an automated endoscope reprocessor (AER)., ${ }^{2,4}$ Gauze or brushes used for cleaning should be disposable, but when using a re-usable brush, the brush must only be used after adequate disinfection. The ideal detergent solution should effectively dislodge contaminants consisting of proteins, fats, carbohydrates, and various chemical bases from the inside of the channels without damaging the equipment; it is recommended to use enzymatic detergent solutions. Clean water should be used to wash out residual detergent from all parts of the endoscope; even when disinfecting endoscopes using an AER, manual cleaning is required up to this step.

\section{Valves and rubber stoppers must be replaced each time.}

Rationale: All valves and rubber stoppers must be replaced after each procedure with disinfected ones. Valves and rubber stoppers contaminated with organic matter and bacteria contaminate disinfected endoscopes and increase the risk of infection. Cleaned valves and rubber stoppers must be rinsed with clean water and subjected to high-level disinfection or sterilization together with the endoscope. The equipment should be stored after sterilization/disinfection as recommended by the manufacturer.

\section{Disinfection: 4 items}

\section{High-level disinfectant must be used.}

Rationale: Although the endoscope may not need sterilization, as it does not come into direct contact with blood vessels, it requires high-level disinfection due to contact with the gastrointestinal mucosa. High-level disinfection refers to a process of eradicating vegetative bacteria (Mycobacterium tuberculosis), some bacterial spores, fungi, and viruses. High-lev- el disinfection effects are exhibited if the manufacturer's recommendations are followed. For sterilization and disinfection, drug or quasi-drug products registered with and approved by the Ministry of Food and Drug Safety must be used in accordance with the usage instructions for each product. High-level disinfectants listed in the "Disinfection Guidelines for Medical Instruments" (Ministry of Health and Welfare) include glutaraldehyde (1.12\% glutaraldehyde $+1.93 \%$ phenol, $3.4 \%$ glutaraldehyde $+26 \%$ isopropanol), orthophthaldehyde $(\geq 0.55 \%$ orthophthaldehyde), peracetic acid and hydrogen peroxide $(7.35 \%$ hydrogen peroxide $+0.23 \%$ peracetic acid, $1 \%$ hydrogen peroxide $+0.08 \%$ peracetic acid, or $7.5 \%$ hydrogen peroxide), and electrolytically generated hypochlorous acid (prepared onsite by electrolysis with $\geq 650-675 \mathrm{ppm}$ active free chlorine content) (revised "Disinfection Guidelines for Medical Instruments" [Minister of Health and Welfare Annoucement 2017-101]). Hypochlorite is a form of electrolytic disinfection water, which can easily become inactive. Therefore, it is considered acceptable if and only if electrolytic disinfection water preparation equipment is available, and hypochlorite is produced onsite for immediate use. ${ }^{4}$

\section{When immersing the components in disinfectant, the biopsy and suction channels must be com- pletely filled with disinfection solution.}

Rationale: Presence of any unfilled spaces inside the biopsy channel and suction channel may allow proliferation of bacteria, and hence, complete disinfection cannot be achieved. The endoscope and all accessories must be completely immersed in disinfectant and the inside of each channel must be completely filled with disinfectant without any unfilled space.

\section{Minimal effective concentrations of high-level disinfectant must be checked and replaced appro- priately.}

Rationale: Most high-level disinfectants are re-usable, but their efficacy may decline due to concentration dilution from long-term and/or repeated use. Therefore, the minimal effective concentration that can retain efficacy must be verified. ${ }^{1,4}$ The minimal effective concentrations of high-level disinfectants should be tested before the start of daily disinfection and after replacing disinfectant to sufficiently maintain the effective concentration. Disinfectants that do not maintain their minimal effective concentration must be discarded, and even if disinfectants still maintain their minimal effective concentration, those that have exceeded the expiration date must also be discarded. To effectively maintain the disinfection effect of high-level disinfectants, it is necessary to learn the replacement cycle of the disinfectant recommended by the manufacturer. The minimum average number of times 
that a high-level disinfectant can be used repeatedly while maintaining its minimal effective concentration should be identified for the specific AER model used and applied within that number of times. Depending on the circumstances of endoscope disinfection, it is recommended that the minimal effective concentration should be checked and the disinfectant be replaced at the appropriate time, even if it has not reached the maximum number of times it could be used.

\section{Disinfectant immersion time should follow the time recommended by the disinfectant manufac- turer.}

Rationale: The most important aspect of disinfection is the type of disinfectant and disinfectant immersion time. For each high-level disinfectant, the protocol recommended by each manufacturer must be followed to ensure that sufficient disinfection is achieved. Therefore, the immersion time based on temperature and conditions of the disinfectant, as recommended by the manufacturer, must be verified before use. After cleaning, all parts of the endoscope, including the biopsy channel, must be sufficiently immersed in disinfectant. Moreover, the user's guide, with information about the ingredients and the usage methods of disinfectants, must be available for proper use and management of disinfectants.

\section{Rinsing: 1 item}

\section{Proper rinsing process is required after disinfec-} tion.

Rationale: This is the process of flushing out residual disinfectant from the endoscope using sterilized or filtered water after disinfection. High-level disinfectant used to disinfect endoscopes may be irritating to the human body and residual disinfectant may cause corrosion of endoscopes. Therefore, thorough rinsing is required. Residual disinfectant may also cause damage to the skin and mucosa, and thus sterilized or filtered water must be used to thoroughly rinse the endoscope, valves, and inside the channels. For proper rinsing, at least 3 times the volume of the area being rinsed is needed. For example, at least $150 \mathrm{~mL}$ of water is needed to rinse a single channel inside the endoscope.

\section{Drying: 2 items}

\section{After rinsing, examinations must be performed after the endoscopy equipment has completely dried.}

Rationale: The process involves removing moisture from the surface and channels of the endoscope. Some bacteria, such as Pseudomonas aeruginosa, thrive in a moist environment, and thus completely drying the endoscope is an important process for preventing infection. After wiping the surface with a clean cloth to remove all moisture, $70 \%-90 \%$ ethyl alcohol or isopropyl alcohol is passed through all channels until it can be seen from the opposite opening, then compressed air is used to dry the channels. ${ }^{1,3}$

\section{Moisture from the exterior of the endoscope and water remaining in the suction channel must be eliminated and then dried by hanging vertically.}

Rationale: This process involves removing moisture from the surface and channels of the endoscope. Some bacteria, such as Pseudomonas aeruginosa, thrive in moist environment, and thus, completely drying the endoscope is an important process for preventing infection. After wiping the surface with a clean cloth to remove all moisture, $70 \%-90 \%$ ethyl or isopropyl alcohol is passed through all channels until it can be seen from the opposite opening and compressed air is used to dry the channels. Alcohol can facilitate drying of the inside of the channels. Compressed air is useful, but one must be cautious as excessively high pressure may damage the soft inner channels of the endoscope. To eliminate any remaining moisture, the endoscope is dried by hanging it vertically with the channels open.

\section{Reprocessing: 1 item}

1. After each examination, one-on-one cleaning, disinfection, and rinsing must be performed.

Rationale: Reprocessing is defined as a series of processes that include cleaning, disinfection, rinsing, and drying. Reprocessing must be performed for each instrument individually to prevent endogenous and exogenous infection.

\section{Storage: 2 items}

1. Disinfected endoscopes must be stored in a dedicated cabinet by hanging vertically, ensuring that the distal end of the endoscope does not touch the floor of the cabinet.

Rationale: To prevent disinfected endoscopes from being contaminated again, endoscopes must be stored by hanging vertically in a doored cabinet in a separate, clean, and dustfree space. Storing in a well-ventilated area helps to continuously dry the surface of the endoscopes and prevent moisture build up. The biopsy channel rubber stopper, suction valve, air/water valve, and waterproof cap must be detached from the endoscope, and the endoscope must be hung vertically without the inner channel blocked in a well-ventilated and clean cabinet. The distal end of the endoscopes must not 
touch the floor of the cabinet when they are hung vertically to prevent tangling. An exception is made for colonoscopes that are longer and may touch the floor when they are hung straight; thus, the floor where the distal end of the endoscope touches should be covered with a clean disinfectant cloth and kept clean and dry. The cabinet must be kept clean by wiping the inside every day with an eco-friendly disinfectant. ${ }^{1,3}$

\section{The cabinet for storing the disinfected endoscope} must be located away from the contaminated area.

Rationale: To prevent disinfected endoscopes from being contaminated again, the cabinet must be located in a separate, clean, and dust-free space, away from the contaminated endoscope cleaning and disinfection areas and the endoscopic examination room that pose a risk of contamination. Storing in a well-ventilated area helps to continuously dry the surface of endoscopes and prevent moisture buildup.

\section{Endoscopic accessories: 1 item}

1. Endoscopic accessories must be disposable products or reusable products that have been sterilized. Rationale: In addition to the spread of infection by the endoscope, there are concerns about spread of infection by inappropriate use and inadequate disinfection of endoscopic accessories. Endoscopic accessories have small gaps and grooves that can easily trap blood and mucous from the patient, which can raise concerns about the spread of infection when reused with inadequate disinfection. Therefore, cleaning, disinfecting, and sterilizing accessories that may spread infection are just as important as disinfecting the endoscope. Endoscopic accessories could be divided into accessories that are assembled at the endoscopy unit and accessories that are inserted into the biopsy channel for the endoscopic procedure. Typical accessories used for endoscopic procedures include biopsy forceps, needles, snares, and mouth pieces, which should be disposable products as a general rule. To prevent infection by accessories, disposable accessories must not be reused by reprocessing. Reusable accessories must follow the reprocessing protocol for cleaning, disinfection, sterilization, and storage.

\section{Water bottle and connectors: 1 item}

\section{Water bottles and connectors must be disinfected regularly, and sterilized water must be used.}

Rationale: While there are no reported data on the potential risk, stability, and optimal replacement cycle of water bottles, lens cleaning solution, connection tubes, vacuum containers for waste storage, and suction tubes, it is recommended that they should be disinfected at least once a day and filled with sterilized water. ${ }^{1,3}$

\section{Space/facility: 4 items}

\section{The endoscope cleansing and disinfection room} must be located in an area separate from the endoscopic examination room, and the room must be kept clean.

Rationale: An endoscopy unit would ideally have an area for performing examinations and procedures and a separate area that holds cleaning and disinfection equipment. A used endoscope that has been contaminated becomes a clean endoscope after going through the processes of cleaning, disinfection, rinsing, and drying, where these processes must be carried out consistently, similar to manufacturing processes.

\section{The endoscope cleaning and disinfection room} must be equipped with an adequate ventilation system.

Rationale: Because disinfectants are handled in the area where endoscopes are cleaned, an adequate ventilation system or hood is needed to prevent disinfection-dedicated workers from becoming exposed to toxic materials. The ventilation system may not only prevent exposure to toxic materials, it may also reduce the risk of infection by a contaminated endoscope. $^{1,5}$

\section{The endoscope cleaning and disinfection area must be divided into contaminated and clean zones.}

Rationale: The endoscope cleaning and disinfection area must be divided into contaminated and clean zones to ensure that the clean zone is not contaminated. In other words, space must be assigned to ensure contaminated endoscopes and reprocessed endoscopes are not in the same area. By assigning space in this manner, the patient's risk of infection or contamination from the examination may be reduced, while also minimizing the risk faced by endoscopy unit workers. The contaminated and clean zones inside the cleansing and disinfection area may be divided by curtains. ${ }^{1}$

\section{Reprocessed endoscopes must be transferred to the endoscopic examination room through a path separate from that of the contaminated endo- scopes.}

Rationale: Areas must be assigned to prevent cross-contamination between contaminated and reprocessed endoscopes and facilitate the transfer of endoscopes. Designated areas must be assigned so that contaminated and reprocessed endoscopes are not in the same zone, and contaminated endo- 
scopes must be transferred from the endoscopic examination room to the contaminated zone through a contaminated path. ${ }^{1}$ Designated areas must be assigned so that the path by which reprocessed endoscopes that have been cleaned and disinfected do not overlap with the path used to transfer contaminated endoscopes (e.g., examination room $\rightarrow$ path $\mathrm{A} \rightarrow$ contaminated zone cleaning and disinfection room $\rightarrow$ clean zone cleaning and disinfection room $\rightarrow$ path $\mathrm{B} \rightarrow$ examination room. Paths A and B must be separate and connected to the examination room through different doors).

\section{Personal protective equipment: 2 items}

\section{All individuals performing endoscopic proce- dures must wear PPE.}

Rationale: PPE must be readied to be worn any time for protection against hazardous materials, blood, and other sources of infection. PPE, such as gloves, mask, eye protection goggles, and closed-toe waterproof shoes must be available.

\section{All workers cleansing and disinfecting endo- scopes must wear PPE.}

Rationale: High-level disinfectants can irritate the eyes, skin, and respiratory system. Therefore, workers who clean and disinfect the endoscopes need to wear PPE, such as a protective mask, gown, and rubber gloves, and an adequate ventilation system is needed. PPE, such as gloves, waterproof gown, mask, eye protection goggles, closed-toe waterproof shoes, and earplugs, must be available and ready to wear in the endoscopy unit. ${ }^{1,6}$

\section{Disinfection ledger: 1 item}

1. In relation to the reprocessing process, data must be managed to be able to differentiate patients, procedure name, the used endoscope and AER, and so on.

Rationale: Endoscope reprocessing needs to be managed, as well as the systematic management of reprocessing abnormalities, damage to the endoscope, or unexpected infection during reprocessing. For this reason, the patient's name and medical record number, the serial number or other identifier of the endoscope and AER used, the date and type of the procedure, and the name of the person performing the reprocessing process are recorded in a ledger and managed accordingly to assist in the investigation when an infection occurs. ${ }^{1,6}$

\section{Regulations regarding infection control and disin-} fection: 3 items

\section{Guidelines stipulating infection control and en- doscope cleaning and disinfection management must be available.}

Rationale: To reduce the frequency of endoscopy-related infections and assure the safety of endoscopy workers and examinees, in-house guidelines on infection control must be available and management according to such guidelines is mandatory. The guidelines for endoscope cleaning and disinfection must follow the endoscope cleaning and disinfection guide from the KSGE that has been certified in Korea. Management is needed to ensure reprocessing is being performed according to the guidelines. Guidelines on whether reprocessing is being performed consistently and high-level disinfection is being maintained must be available as well. Guidelines on management of AER, disinfectants, sterilization accessories, and storage after disinfection must be available. Moreover, an in-house disinfection manual must be prepared and made available, while quality control in disinfection must be maintained by creating a checklist.

\section{In-house disinfection education must be conduct- ed for quality control of endoscope disinfection.}

Rationale: Depending on the institution, there may be cases in which some workers may need to participate in endoscope disinfection work without attending disinfection education sponsored by the academy. In such cases, appropriate education must be conducted prior to participating in such work.

\section{Bacterial culture tests must be performed at least twice a year for quality control of endoscope dis- infection.}

Rationale: Bacterial culture tests must be conducted regularly in accordance with the infection control guidelines of each institution to maintain high-level disinfection of endoscopes. The results of such tests must be recorded and kept. Regulations on infection control in the endoscopy unit, guidelines on regular inspection of endoscope reprocessing, and bacterial culture test records must be available. Bacterial culture tests must be performed at least twice a year, while additional tests may be performed if deemed necessary.

\section{CONCLUSIONS}

Thorough disinfection and infection control associated with gastrointestinal endoscopy is very important for the health and safety of the examinee as well as the medical staff involved in the procedure. All endoscopists and workers who clean and disinfect endoscopes should receive regular disinfection education and try to conduct thorough management 
for disinfection and infection control. The updated AQEU assessment items for disinfection and infection control are expected to help to improve the quality control of endoscopy by thorough management of endoscopic cleaning and disinfection.

Conflicts of Interest

The authors have no financial conflicts of interest.

\section{ORCID}

Yunho Jung: https://orcid.org/0000-0002-7760-0050

Jeong Hoon Lee: https://orcid.org/0000-0002-0778-7585

Byoung Kwan Son: https://orcid.org/0000-0002-9299-5476

Jae-Young Jang: https://orcid.org/0000-0002-7930-1468

Hyung-Keun Kim: https://orcid.org/0000-0003-3138-0141

Byung Ik Jang: https://orcid.org/0000-0002-3037-9272

\section{REFERENCES}

1. Reprocessing Guideline Task Force, Petersen BT, Cohen J, et al. Multisociety guideline on reprocessing flexible GI endoscopes: 2016 update. Gastrointest Endosc 2017;85:282-294.e1.

2. Beilenhoff U, Biering H, Blum R, et al. ESGE-ESGENA technical specification for process validation and routine testing of endoscope reprocessing in washer-disinfectors according to EN ISO 15883, parts 1, 4, and ISO/TS 15883-5. Endoscopy 2017;49:1262-1275.

3. Son BK, Kim BW, Kim WH, Myung DS, Cho YS, Jang BI. Korean Society of Gastrointestinal Endoscopy guidelines for endoscope reprocessing. Clin Endosc 2017;50:143-147.

4. ASGE Technology Committee, Parsi MA, Sullivan SA, et al. Automated endoscope reprocessors. Gastrointest Endosc 2016;84:885-892.

5. Kovaleva J. Infectious complications in gastrointestinal endoscopy and their prevention. Best Pract Res Clin Gastroenterol 2016;30:689-704.

6. Beilenhoff U, Biering H, Blum R, et al. Reprocessing of flexible endoscopes and endoscopic accessories used in gastrointestinal endoscopy: position statement of the European Society of Gastrointestinal Endoscopy (ESGE) and European Society of Gastroenterology Nurses and Associates (ESGENA) - update 2018. Endoscopy 2018;50:1205-1234. 